\title{
Dynamics of Water-Salt Regime of Meadow Saline Soils Foothill Plain of the Ili Alatau
}

\author{
Aigul Beketova, Saginbay Kaldybayev, Zhainagul Ertayeva ${ }^{1}$ \\ ${ }^{1}$ Kazakh National Agrarian University, Almaty, Kazakhstan
}

\begin{abstract}
Almost the entire territory of the Republic of Kazakhstan belongs to the undrained land area where concentrated large areas of saline soils CIS and therefore it is one of the most saline parts of Central Asia.

Studying the dynamics of salt regime of irrigated soils is actual and for evaluation of applicable meliorations and finding ways to increase their effectiveness in the saline areas of Kazakhstan. In this regard, studies were carried out on a previously meliorated meadow solonchak soils under natural conditions and under lucerne (Teskensu Farm foothill plain of Ili Alatau, Almaty region).

As a result of studies data was taken which allow to evaluate the water-salt regimes.
\end{abstract}

Keywords: solonchak soils, melioration, desalination, salinity, seasonal accumulation of salts.

\section{Introduction}

Throughout the history of soil science saline soils are one of the main objects of study in many countries. This is because, firstly, the prevalence of saline soils in different regions of the Earth; secondly, the fact that salinity is one of the principal genetic properties and reclamative peculiarities of arid and semi-arid area soils, as well as property, limiting their fertility. And finally, thirdly, salinity is one of the main signs of unfavorable ecological state of lands.

Saline soils are spread across all continents, they are found in 100 countries around the world and practically in all natural zones, but dominate in the areas of steppes, semi-deserts and deserts. At the same time saline soils in different regions differ significantly in properties, genesis, and hence the reclamation methods, which causes the differences in their development, management and salinity control [1].

Resalinization of irrigated lands causes great damage to agriculture. The main reason of this harmful phenomenon is the absence of an engineering collector-drainage networks in low natural drainage of groundwater. Deterioration of water-salt relations leads to a decrease in the productivity of irrigated lands and the loss of the irrigated lands from agricultural use [2].

Irrigated lands are a vulnerable component of the environment and any disturbance of the natural and reclamation systems balance can lead to irreversible environmental consequences. As a result of economic reforms in agriculture a violation of the structure of crops takes place on irrigated lands, agricultural machinery cultivation and irrigation technology are not maintained, about 50\% of these lands are not used in the last years, which is likely to disrupt established ecosystems balance.

According to long-term observations of the ameliorative condition of soil in Almaty Oblast it is found that in the irrigated lands exploitation process there is a decrease in soil fertility, which is manifested in a decrease in reserves of humus and nutrients, deterioration of water-physical properties of soils, development of salinity, alkalinity and soil erosion processes [3-5]. The most intensive development of salinization processes are observed in the last 6-8 years. This is a consequence of the crisis which has affected agricultural production these years. Due to lack of financial and material resources, repair works of irrigation and collector-drainage systems are not performed in a timely manner, which is why irrigation regimes are broken, agricultural machinery is not maintained and there is no crop rotation. 
Processes of soil salinity occur almost throughout the region, depending on the system of irrigated agriculture, climatic-natural and hydrogeological conditions

\section{Materials and methods}

In key areas (For sowing lucerne and the control section for the definition of seasonal salt accumulation SASA at drain spacing of $200 \mathrm{~m}$ ) soil samples were selected every $20 \mathrm{~cm}$ to $1 \mathrm{~m}$. Field, stationary, laboratory and analytical methods were applied for the research.

\section{The results of researches and discussion}

Salt regime of soils under natural conditions (previously reclaimed, leaching rate of $5000 \mathrm{~m} 3 / \mathrm{ha}$, drain spacing of $200 \mathrm{~m}$.) in the annual cycle is subject to significant change. According to salt reserves in the meter thickness it was formed according to seasonally irreversible type of salinization.

Winter and spring abundant soil moisture contributes to the removal of soluble salts in the groundwater. As a result, fewer salts of $28.698 \mathrm{t} / \mathrm{ha}$ in the meter thickness were found in the soil-ground profile (Table 1).

TABLE 1 - Dynamics of salt reserves in 0-100 cm layer (t/ha) in drain spacing of $200 \mathrm{~m}$. (2015)

\begin{tabular}{|c|c|c|c|}
\hline Spring & Summer & Autumn & SAS ratio \\
\hline 28.968 & 32.439 & 86.513 & 2.98 \\
\hline
\end{tabular}

During the summer-autumn period of the first year of studies, due to a decrease in soil moisture and groundwater level, there is the opposite phenomenon, namely due to strong evaporation and rising salts current there is soil salinization and the most extent in autumn: in summer salt reserves were 32.439 and in autumn $86.513 \mathrm{t} / \mathrm{ha}$ (2015), which proves the process of seasonally irreversible salinization.

In the salt composition mostly $\mathrm{SO}_{4}^{2-}$ and $\mathrm{Ca}^{2}+, \mathrm{Na}+$ ions dominate which indicates the sulphate, calcium and sodium type of salinity. In spring the content of sulfate ion in the meter layer ranged $0,300-0,069 \%$ and in autumn it has risen to $1.033-0.075 \% . \mathrm{Ca}^{2+}$ ion increases in the amount of from 0.082 to $0.150 \%$, and $\mathrm{Na}^{+}$ion increases in the amount from 0.028 to $0.055 \%$ (in a layer $0-20 \mathrm{~cm}$.). Also, due to the greater mobility of the chloride content in the annual cycle, there is some increase from 0.006 to $0.012 \%$.

Thus, in the seasonal cycles of salt regime of previously reclaimed meadow solonchak in natural conditions in the investigated year the spring desalination and the summer-autumn salinity periods are observed. Since SAS ratio is greater than one (2.98), the process of seasonally irreversible salinization has been formed in the soil.

Salt regime in in natural conditions (wild land, previously reclaimed) at drain spacing of 200 meters in the annual cycle for salt reserves in the meter thickness $(0-100 \mathrm{~cm})$ also was formed according to seasonally irreversible salinization type.

If the salt reserves amounted to $225.754 \mathrm{t} / \mathrm{ha}$ in spring, during the summer-autumn period due to strong evaporation and salt rising current there is soil salinization mostly in autumn: salt reserves were 249.643 in summer, and 253.292 t/ha in autumn. (table 2).

TABLE II - Dynamics of salt reserves in 0-100 cm layer (t/ha) in drain spacing of $200 \mathrm{~m}$.(wild land, 2016)

\begin{tabular}{|c|c|c|c|}
\hline Spring & Summer & Autumn & SAS ratio \\
\hline 225.75 & 249.64 & 253.29 & 1.12 \\
\hline
\end{tabular}

The seasonal accumulation of salts (SAS) ratio was greater than one (1.12) which proves the process of seasonally irreversible salinization. The salt composition is mostly dominated by $\mathrm{SO}_{4}{ }^{2-}$ and $\mathrm{Ca}^{+}{ }^{2}, \mathrm{Na}^{+}$ions, indicating the sulphate, calcium and sodium salinity. In spring the content of sulfate ion in the meter layer 
ranged within $0.810-1.205 \%$ and it amounted to $1.152-1.200 \%$ in autumn. $\mathrm{Ca}^{2+}$ ion was from 0.100 to $0.264 \%$, and the $\mathrm{Na}^{+}$ion was from 0.125 to $0.309 \%$. Also, there is some increase in the chloride from 0.017 to $0.093 \%$.

Salt regime of soil under alfalfa of first and second year of life (2015-2016) previously reclaimed meadow solonchak was formed by seasonally irreversible desalinization types (table 3).

TABLE III - Dynamics of salt reserves in 0-100 cm layer ( $\mathrm{t} / \mathrm{ha}$ ) on the key area (alfalfa, average for 2 years)

\begin{tabular}{|c|c|c|c|}
\hline Spring & Summer & Autumn & SAS ratio \\
\hline 43.12 & 43.24 & 33.63 & 0.780 \\
\hline
\end{tabular}

In the spring salt reserves are $43.12 \mathrm{t} / \mathrm{ha}$, in the summer growing season there is some reduction of salt reserves in the soil up to $43.24 \mathrm{t} / \mathrm{ha}$. In the autumn seasonal desalination exceeded seasonal salinity - $33.63 \mathrm{t} / \mathrm{ha}$. SAS ratio is 0.78 , which shows the process of seasonally irreversible desalinization.

If at the end of the third year of lucerne (1989) the amount of salt in the upper 0-40 cm layer was 0.388 $0.620 \%$, after a long post-reclamation period (autumn, 2016.) $-0.440-0.397 \%(0-40 \mathrm{~cm})$, i.e. there was some desalinization of soil during this period.

It should be noted that an active role in the resumption of land salinization has pressure groundwater supply of sasa strips of Ili Alatau piedmont plain. That pressure groundwater supply is an inexhaustible supplier of salts in the upper layers of the soil and groundwater. These waters have hydro-calcium composition and contain

\section{Conclusion}

Thus, in the seasonal cycles of salt regime of previously reclaimed meadow solonchaks in natural conditions in the investigated year it was observed periods of the spring desalination and the summer-autumn salinity. Since SAS ratio is greater than one, there was a seasonally irreversible salinization process in the soil. Salt regime of soil under first and second year alfalfa of previously reclaimed meadow solonchaks was formed by a seasonally irreversible desalinization.

\section{References}

[1] L.V. Berezin, A.S. Saparov, V.M. Kang, M.R. Shayahmetov Technology for complex reclamation of Russia and Kazakhstan ecosystem, LLP "Printing and service $\mathrm{K}^{0}$ ", Almaty-Omsk.: 2013, 215p.

[2] A Saparov, Chen Shi, Zili Abduvayli. The soils of the arid zone of Kazakhstan: current state and their use, LLP "Printing and service $\mathrm{K}^{0}$ ", Almaty, 2014, 440p.

[3] T.T. Tazabekov. "Meadow reclamation salt marshes in the area BAR", Irrigation and Water Management, vol.12, pp.21-22, 1990.

[4] B. D. Seelig, and J. L. Richardson. Salinity and sodicity in North Dakota soils. North Dakota, State Univ. Extension Service Bulletin 57, 1991.

[5] S.Kaldybaev Saline soils of Kazakhstan and their reclamation. Almaty: Dulat, 2014, 484p. 